\title{
Migration and Remittance: A Boon for Indian Economy
}

Mohammad Saif Ahmad*

Western Institute of Technology, Melbourne, Australia

*Corresponding author: Mohammad Saif Ahmad, Trainer and Assessor, Western Institute of Technology, Melbourne, Australia, Tel: +61 3 9017 5033; E-mail: msaifahmad@gmail.com

Received date: July 23, 2014; Accepted date: August 01, 2014; Published date: August 07,2014

Copyright: () 2014 Mohammad Saif Ahmad. This is an open-access article distributed under the terms of the Creative Commons Attribution License, which permits unrestricted use, distribution, and reproduction in any medium, provided the original author and source are credited

\begin{abstract}
As an external source of financing Indian migrants" remittances have been playing very important role in India's macro and micro economic development. It has been higher than the foreign direct investment as well as foreign portfolio investment. It is also more than three times than the official development aid. In 2013, remittances to amounted to 70 billion US\$, the highest in the world. Throughout the 1990s, they offset country's merchandise deficit to a large extent and also presently amounts to nearly 4 percent of the Indian Gross Domestic Product. The remittance figures would get larger if you also consider the large amounts of 'hawala' transactions that are illegal. The paper deals with the emerging trends with respect to remittance inflows and other major issues related thereto.
\end{abstract}

Keywords: Diaspora; Emigrants; Foreign exchange; Foreign portfolio investment; Financial institutions; IT exports; Microeconomic finance institutions; Remittances.

\section{Introduction}

In the present globalized world, migration of people from one country to another for employment has become a common phenomenon. The socio-economic conditions prevailing in migrationsending and migration-receiving countries have led to the formation of dominant migration corridors between various countries/regions. Lack of job opportunities, lower wage rates, social insecurity, extreme geographical conditions and political instability in migration-sending countries coupled with availability of employment opportunities friendly migration policies, shortage of skilled resources, abundance of natural resources and financial liberalization in migration-receiving countries are the prime movers for this state of affairs. Globally, there were 232 million international migrants in 2013 of which nearly 59 percent (136 million) lived in developed countries while the developing nations hosted 41 per cent (96 million) of the world's total. During 2000-2010, some 4.6 million migrants were added annually compared to an average of 2 million per annum during the period of 1990-2000. Of the top ten countries which accommodated over 51 percent of all international migrants, USA accounted for 45.8 million, equal to nearly 20 percent of the world's total, Russian Federation hosted 11 million followed by Germany (9.8 million), Saudi Arabia (9.1 million), the UAE (7.8 million), United Kingdom (7.8 million), France (7.4 million), Canada (7.3 million), Australia ( 6.5 million) and Spain (6.5 million).

Nobody can doubt the contribution of external sources of financing in the economic development of any country. For , international migrants remittances, as external sources of financing, have consistently been higher and more stable than foreign direct investment and foreign portfolio investment. Also, they have been more than three times the official development aid (ODA). had been facing acute foreign exchange crisis right from its independence in 1947 and remittances have thus served as blessings in many ways. In overall context, remittances have been serving as an antidote to poverty while simultaneously promoting prosperity. In 2013, India received (see Figure 1) 70 billion US\$ in remittances, China, 60 billion, the Philippines 25 billion, Mexico 22 billion, Nigeria 21 billion, Egypt 17 billion, Pakistan 15 billion, Bangladesh 14 billion, Vietnam 11 billion and Ukraine 10 billion, as depicted in Table 1. In India, remittances were more than 65 billion $\$$ earned from the country's flagship software services exports. These figures will got larger if illegal 'Hawala' or 'Hundi' transactions are also taken into account. In fact, it is an informal value transfer system based on the performance and honour of a huge network of money brokers, which are primarily located in the Middle East, North Africa, the Horn of Africa and the Indian subcontinent. Although the exact amount of remittances transferred through the 'hawala' system is difficult to measure, some studies estimate that the hawala market in could be as large as 30 to 40 percent of the recorded remittance transfers. The characteristics of 'hawala' money transfers include ease of operation, lower transfer costs, speed, potential anonymity and convenience which explain their usage even today.

According to [1] United Nations International Migration 'Report', 2013, 232 million people live outside their countries of birth. In the coming decades, demographic forces, globalization, and climatic changes will increase migration pressures both within and across borders. As per the latest issue of the Migration and Development Brief of the World Bank. International migrants from developing countries are expected to send $\$ 436$ billion in remittances in 2014 to their home countries, despite more deportations from some host countries, resulting in an increase of 7.8 per cent over 2013.

China has clear lead over India in matters of population, manufacturing, exports, energy, infrastructure development and overall management and administration of its national economy. But India has been enjoying an edge over China in matters of remittances and Diaspora numbers for the last so many years. According to [2] Ministry of Overseas Indian Affairs (MOIA), currently 30 million Indians have been working in different fields across the globe vis-à-vis 35 million Chinese Diaspora numbers. But China includes immigrants from Hong Kong and Taiwan in its Diaspora population. If India calculates the figures of remittances the way China does, it should 
Page 2 of 3

include the Diaspora of Pakistan and Bangladesh in its figures of remittances because both the countries are of the same ethnic stock and were once part of India. Even Myanmar (Burma) was also once part of India. Presently, Pakistan and Bangladesh are independent countries and their figures are separately considered as such. Even economic growth rates of India and China cannot be strictly compared and many experts believe that Chinese growth rates could be easily lowered by one per cent because the Chinese have their peculiar style of calculating statistics.

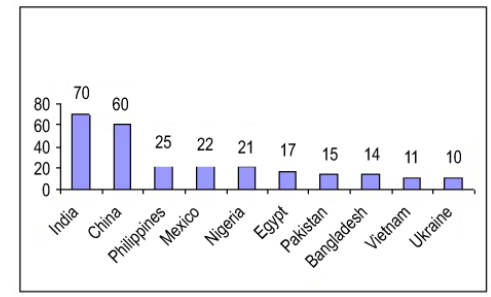

Figure 1: Top Ten Recipients of Remittanes in billion US\$ (2013). Source: World Bank Statistics.

\begin{tabular}{|l|l|l|}
\hline S.No. & Countries & $\begin{array}{l}\text { Numbers } \\
\text { (Million) }\end{array}$ \\
\hline 1 & North America (mostly USA and Canada) & 4 \\
\hline 2 & $\begin{array}{l}\text { Europe (U.K., Netherlands, Germany, Austria, Switzerland } \\
\text { etc.) }\end{array}$ & 2.5 \\
\hline 3 & Africa (South Africa, Mauritius, East African countries) & 2.7 \\
\hline 4 & Middle East (Saudi Arabia, UAE, Kuwait etc.) & 3.6 \\
\hline 5 & $\begin{array}{l}\text { Far East \& South East Asia (Malaysia, Singapore, } \\
\text { Myanmar etc.) }\end{array}$ & 5 \\
\hline 6 & Sri Lanka and Nepal & 4.9 \\
\hline 7 & $\begin{array}{l}\text { South America (Trinidad \& Tobago, Guyana, Suriman, } \\
\text { Jamaica etc.) }\end{array}$ & 1.6 \\
\hline 8 & $\begin{array}{l}\text { Pacific Countries and Islands (Australia, New Zealand, Fiji } \\
\text { etc.) }\end{array}$ & 0.7 \\
\hline & TOTAL & 25 \\
\hline
\end{tabular}

Table 1: Indian Diaspora Numbers; Source: Since hard numbers have not been available, these are approximate estimates collected from different sources of individual country statistics and from various reports and sources.

\section{Remittances and Overall Development}

In fact, migration, accompanied by remittances positively contributes to the overall economic development [3] of a country that ultimately results in poverty reduction, social empowerment and technological progress. , being the largest recipient of remittances in the world, has well enjoyed these benefits during the last three decades. Throughout the 1990s, they offset country's merchandise trade deficit to a large extent. These receipts have also served as one of the least volatile inflows in either the current or capital account of 's balance of payment.
In broad terms, gains from remittances can be realized at both the macro level (effects on the national economy) and the micro level (effects on recipient region and households). Undoubtedly, much of the developmental impact of remittances will depend on the magnitude of its value and how productively the receiving economy and households use it. At the macro level, the most direct and significant impact of remittances is on the volume of foreign exchange reserves. As they are part of balance of payment account, the increase in it can reduce the BOP deficit (particularly current account deficit) that ultimately results in conducive environment for foreign investment in the country. Additionally, it also solves the financial constraints faced by many small scale enterprises by utilizing migrants' family small savings if the financial institutions in the country are strong enough.

At the micro level, the money sent by the migrants to their families are used for consumption (durables and non-durables both), education, health, asset creation by building houses and buying lands, loan repayments, small savings and so forth. If the remittances are used for buying commodities of daily use, it definitely leads to the development and expansion of manufacturing sector of the country by increasing the demand for goods from this sector. It will ultimately lead to demand for labour thus increasing their income distribution. All of these expenditures will have their multiplier effects on the local economy of the region.

If the remittances are invested in some productive activities like investment in agriculture for buying some inputs or setting up some agro-based entrepreneurial unit, it will have more stable and long lasting impact on the income levels of households of that particular region. Lastly, all the money sent by the migrants is not spent completely, rather a part thereof is deposited in the banks which serves as a means of financing loans to other households leading to overall entrepreneurial development of the concerned area.

\section{Phases of Migration}

In historical perspective, migration of labour across national boundaries is not new to any developing countries including India and dates back to several centuries. The contacts with Persian Gulf region and South East Asia, in terms of both trade in goods and movement of people, also go back to several centuries. The migration of labour on mass scale began within the colonial era. This trend continued even after mid-Twentieth Century when most of the developing countries got rid of direct colonial rule. In India, the first phase of international migration began in the early 1950s which was characterized by a movement of technically qualified and professionally competent persons to the industrialized countries like the USA, UK, Canada, , Singapore etc.

The second phase of international migration was largely to the oilexporting countries of the Middle East in mid 1970s that peaked in early 1980s as the dramatic increase in oil prices led to an economic boom in these labour-scarce countries. A large number of skilled and semi-skilled workers migrated to Gulf countries during this period. The third phase of migration began in early 1990s when economic reforms were introduced by the Government of India accompanied by the Information and Communication Technology revolution in the country. All through the phases enumerated above, India has been playing a significant role in providing labour force to the labourscarcity regions of the world. A number of factors responsible for the 
continuing state of affairs that have contributed in out migration from different states of India have already been mentioned above.

\section{Domination of Gulf Countries}

In matters of remittances, special mention has to be made of the Gulf countries because for Indian sub-continent it is undoubtedly very huge market. The largest number of unskilled and semi-skilled Indian immigrants go to the Middle East, particularly to Saudi Arabia, UAE, Kuwait, Bahrain, Oman and . They are mainly getting employment in (a) white collar jobs (doctors, nurses, engineers, architects, accountants and managers), (b) blue collar jobs (semi-skilled workers) like craftsmen, drivers, artisans and other technical workers and (c) unskilled labourers in construction works, farmlands, livestock ranches, shops, stores and household maids and other domestic works. The first category comprises about 30 per cent of Indian immigrants in six GCC countries while the last two categories comprise almost 70 per cent of all Indian immigrants. Within the GCC countries, Kingdom of Saudi Arabia and UAE are the most popular destinations of Indian immigrants and together they are responsible for more than 60 per cent of the total deployment of Indian migrant workers in the Middle East.

The Government of India has substantially deregulated the banking and finance sector over the years and now the migrants can hold a lot more in their accounts and invest a lot more than ever before. The continuous depreciation of Indian rupee vis-à-vis US dollar over the post so many years and the rising interest rates make Indian rupee very attractive to NRIs. The migrants accumulate dirhams with an eye on exchange rates and remit funds [4] as soon as the rupee falls. But the value of Indian rupee depends on a number of factors beyond the control of the Government of India as transactions worth trillions of US dollars take place outside the jurisdictions of RBI and SEBI. In fact, stock and forex markets, with all kinds of refinements and sophistications, thrive on economic framework failures and migrants also take advantage of the same. This results in increased remittances to India from the Gulf countries.

India is the largest recipient of migrants' remittances in the world which comes to roughly 4 per cent of India's Gross Domestic Product (GDP). The Middle East [5], Saudi Arabia and United Arab Emirates are the prime sources of remittances. Remittances from North America [6,7], especially the USA and Canada, have increased substantially since the 1990s because of large emigration of highly skilled workers. The increasing shares of North America and the Middle East over the years have led to a fall in the relative share of Europe [8-10] in remittance inflows. These remittances have, over the years, grown in importance in sustaining many regional economies at the macro and micro levels.
Remittances are also rightly called the most riskless and least volatile sources of external development finance for well-known reasons. Foreign capital tends to flow more in favourable time and less in bad times. But remittances tend to react less violently and even increases in bad times. For example, remittances to developing countries continued to rise steadily during 1998-2001 when private capital flows, including FDI, declined in the wake of East Asian crisis. Just like FDI and FIIs, remittances can also be a great source of development finance both at micro and macro levels. Migration remittances can be used for creating assets, small savings or setting up some small businesses. The investment in education and health can have positive impact on the human capital formation which will be beneficial for both the country and the family as a whole. The small savings by the migrants family can also be an investment for the industrial sector if the financial institutions utilize it properly

Here, microfinance institutions can play a significant role by capturing and transferring remittances to entrepreneurs who can fuel productive activities. Continuous remittance inflows also create positive atmosphere for making a country creditworthy. It definitely enhances a country's access to international capital market, that is, foreign institutional investments for financing a number of infrastructural and development projects.

\section{References}

1. United Nations Department of Economic and Social Affairs/Population Division, (2013) International Migration Report.

2. Ministry of Overseas Indian Affairs, Government of India, New Delhi, 2012.

3. Sunny Kumar Singh and K.S. Hari (2011) International Migration, Remittances and its Macroeconomic Impact on Indian Economy W.P. No. 2011-01-06, IIM Ahmedabad, p.15.

4. IMF Occasional Paper No. 259 (2008) Macroeconomic Consequences of Remittances, International Monetary Fund, Washington DC.

5. Azeez A. and Begum M. (2009). Gulf Migration Remittances and Economic Impact, Journal of Social Sciences, 20(1), 55-60.

6. Ratha D. (2007). Leveraging Remittances for Development, Policy Brief, Migration Policy Institute, Washington DC.

7. Chishti A.M (2007). The Phenomenal Rise in Remittances to India: A Closer Look, Policy Brief, Migration Policy Institute, Washington DC.

8. Desai et al. (2009). The fiscal impact of high-skilled emigration to US, Journal of Development Economics (88), 32-44.

9. Gabi G.A (2012). The Remittance Market in India - Opportunities, Challenges and Policy Options. The World Bank, Washington DC.

10. World Migration Report (2013). International Organization for Migration, Geneva, Switzerland. 